\title{
Endogenous Signaling through $\alpha 7$-Containing Nicotinic Receptors Promotes Maturation and Integration of Adult-Born Neurons in the Hippocampus
}

\author{
Nolan R. Campbell, ${ }^{1}$ Catarina C. Fernandes, ${ }^{1,2}$ Andrew W. Halff, ${ }^{1}$ and Darwin K. Berg ${ }^{1}$ \\ ${ }^{1}$ Neurobiology Section, Division of Biological Sciences, University of California, San Diego, La Jolla, California 92093-0357, and ${ }^{2}$ Institute of Pharmacology \\ and Neurosciences, Faculty of Medicine and Unit of Neurosciences, Institute of Molecular Medicine, University of Lisbon, 1649-028 Lisbon, Portugal
}

\begin{abstract}
Neurogenesis in the dentate gyrus occurs throughout adult mammalian life and is essential for proper hippocampal function. Early in their development, adult-born neurons express homomeric $\alpha 7$-containing nicotinic acetylcholine receptors ( $\alpha 7$-nAChRs) and receive direct cholinergic innervation. We show here that functional $\alpha 7$-nAChRs are necessary for normal survival, maturation, and integration of adult-born neurons in the dentate gyrus. Stereotaxic retroviral injection into the dentate gyrus of wild-type and $\alpha 7$-knock-out ( $\alpha 7 \mathrm{KO}$ ) male and female mice was used to label and birthdate adult-born neurons for morphological and electrophysiological measures; BrdU (5-bromo-2-deoxyuridine) injections were used to quantify cell survival. In $\alpha 7 \mathrm{KO}$ mice, we find that adult-born neurons develop with truncated, less complex dendritic arbors and display GABAergic postsynaptic currents with immature kinetics. The neurons also have a prolonged period of GABAergic depolarization characteristic of an immature state. In this condition, they receive fewer spontaneous synaptic currents and are more prone to die during the critical period when adult-born neurons are normally integrated into behaviorally relevant networks. Even those adult-born neurons that survive the critical period retain long-term dendritic abnormalities in $\alpha 7 \mathrm{~K} 0 \mathrm{mice}$. Interestingly, local infection with retroviral constructs to knockdown $\alpha 7$-mRNA mimics the $\alpha 7 \mathrm{~K} 0$ phenotype, demonstrating that the relevant $\alpha 7$-nAChR signaling is cell autonomous. The results indicate a profound role for $\alpha 7$-nAChRs in adult neurogenesis and predict that $\alpha 7$-nAChR loss will cause progressive impairment in hippocampal circuitry and function over time as fewer neurons are added to the dentate gyrus and those that are added integrate less well.
\end{abstract}

\section{Introduction}

Continuing neurogenesis in the adult dentate gyrus is necessary for hippocampal function (Shors et al., 2001, 2002; Rola et al., 2004; Snyder et al., 2005; Winocur et al., 2006). Abnormalities in adult neurogenesis are likely to exacerbate major neurological disorders, including Alzheimer's disease and depression (Gough, 2007; Sahay and Hen, 2007; Verret et al., 2007; Kotani et al., 2008; Perera et al., 2008) and contribute to addiction and relapse behavior (Noonan et al., 2010). Understanding how adult-born neurons develop and integrate into preformed neural networks may suggest targets for therapeutic intervention and assist in developing stem cell therapies for repairing damaged neuronal tissue (Sohur et al., 2006; Okano and Sawamoto, 2008).

Pioneering work on adult neurogenesis indicates that ionotropic receptor signaling plays important roles. Depolarizing GABAergic activity alters precursor proliferation and is necessary

Received Feb. 19, 2010; revised April 19, 2010; accepted May 12, 2010.

This work was supported by National Institutes of Health Grants NS012601 and NOS35469, and the TobaccoRelated Disease Research Program (16RT-0167). N.R.C. is a Tobacco-Related Disease Research Program predoctoral fellow. C.C.F. is a Fundação Calouste Gulbenkian Graduate Fellow. A.W.F. is a National Research Service Award predoctoral fellow. We thank Gouping Feng (Duke University, Durham, NC) for the GFP-reporter mouse line and Xiao-Yun Wang for expert technical assistance.

Correspondence should be addressed to Darwin K. Berg, Division of Biological Sciences, University of California, San Diego, 9500 Gilman Drive, La Jolla, CA 92093-0357. E-mail: dberg@ucsd.edu

D0I:10.1523/JNEUROSCI.0931-10.2010

Copyright $\odot 2010$ the authors $\quad 0270-6474 / 10 / 308734-11 \$ 15.00 / 0$ for dendritic growth of adult-born neurons (Liu et al., 2005; Ge et al., 2006). Glutamatergic activity through NMDA receptors encourages survival of adult-born neurons during a critical period when the neurons are first assimilated into behaviorally relevant networks (Tashiro et al., 2006, 2007). Nicotinic cholinergic input is also positioned well to influence adult neurogenesis. Early on, the neurons receive cholinergic innervation and express two major types of ionotropic nicotinic acetylcholine receptors (nAChRs): homopentameric $\alpha 7$-containing receptors ( $\alpha 7$-nAChRs) and heteropentameric $\beta 2$-containing receptors ( $\beta 2^{\star}$-nAChRs) (Kaneko et al., 2006; Ide et al., 2008).

Substantial evidence indicates that cholinergic signaling regulates adult neurogenesis. Cholinergic forebrain lesion decreases adult-born neuron survival, and enhancing cholinergic activity increases survival (Cooper-Kuhn et al., 2004; Kaneko et al., 2006). Chronic nicotine exposure in vivo reduces adult-born neuron proliferation (Abrous et al., 2002; Shingo and Kito, 2005; Scerri et al., 2006), whereas $\beta 2$-nAChR knock-out (KO) mice show decreased proliferation, but normal survival, of hippocampal adult-born neurons (Harrist et al., 2004; Mechawar et al., 2004). Contributions of $\alpha 7$-nAChRs to adult neurogenesis are unknown.

In early postnates, $\alpha 7$-nAChRs contribute importantly to hippocampal development. Young hippocampal neurons in $\alpha 7 \mathrm{KO}$ mice have a prolonged period of GABAergic excitation because of delayed appearance of the mature chloride transporter KCC2 and 
extended presence of the immature chloride transporter NKCC1 (Liu et al., 2006). Furthermore, $\alpha 7$-nAChR signaling helps drive giant depolarizing potentials that shape network development and contribute to synaptic plasticity (Maggi et al., 2001, 2003; Le Magueresse et al., 2006). Subsequent $\alpha 7$-nAChR activity enhances both GABA and glutamate release (Gray et al., 1996; Alkondon et al., 1997a; Radcliffe and Dani, 1998; Alkondon and Albuquerque, 2001).

Here, we show that adult-born neurons in $\alpha 7 \mathrm{KO}$ mice receive fewer spontaneous synaptic currents and are disadvantaged for survival during the critical period in vivo. The neurons develop with severely truncated dendritic arbors, a prolonged depolarizing chloride gradient, and GABAergic currents with immature kinetics. These results indicate that $\alpha 7-\mathrm{nAChR}$ signaling modulates the tempo of adult-born neuron physiological and morphological development. We further demonstrate that this function results from cell-autonomous $\alpha 7$-nAChR signaling and is necessary to prevent persistent morphological abnormalities of granule cells in the dentate gyrus.

\section{Materials and Methods}

Transgenic animals. All mice were C57BL/6 background and used at 1-3 months of age. Control and experimental mice were age-matched in all experiments. Heterozygous $\alpha 7 \mathrm{KO}$ mice were purchased from The Jackson Laboratory. Their offspring were genotyped by PCR, and homozygous $\alpha 7 \mathrm{KO}$ mice were used for experiments. GAD67-GFP mice, generated and provided by Guoping Feng (Duke University, Durham, NC), were crossed with the $\alpha 7 \mathrm{KO}$ mouse line. To ensure that only GAD67-GFP heterozygous mice were used in experiments, homozygous GAD67-GFP mice were bred with nulls to produce test animals.

RNA interference constructs. Lentiviral vectors were constructed to reduce $\alpha 7$-mRNA levels in vivo by RNA interference ( $\alpha 7 \mathrm{RNAi}$ ). A Genscript algorithm was used to design sequences uniquely homologous to mouse $\alpha 7$ mRNA. A control scrambled sequence was obtained with Genscript sequence scrambler and shown not to be homologous with any sequence in the mouse genome. The sequences were inserted into lentiviral vectors (FG12; Addgene plasmid 14884) under an $\mathrm{H} 1$ promoter along with green fluorescent protein (GFP) under a ubiquitin promoter and linked to their reverse complement by the loop sequence TCTCTTGAA to form short-hairpin RNAs. Their compositions are as follows: $5^{\prime}$-AGGCAGATATCAGCAGCTATA-3', 5' -ACCACCAACATTTGGCTACAA-3', and 5' GAGAGTACGCTAAGATCCTAA- $3^{\prime}$ for $\alpha 7$ RNAi-1, $\alpha 7$ RNAi-2, and scrambled RNAi, respectively. The effectiveness of the lentiviral $\alpha 7 \mathrm{RNAi}$ constructs was tested by infecting 16-d-old mouse (embryonic day 18 C57BL/6) hippocampal $3.5 \mathrm{~cm}$ cultures (plated at $62,500 \mathrm{cells} / \mathrm{cm}^{2}$ ) with 5 $\mu \mathrm{l}$ of virus stock $\left(1 \times 10^{8} \mathrm{PFU} / \mathrm{ml}\right)$, and collecting the cells 1 week later (supplemental Fig. 1, available at www.jneurosci.org as supplemental material). Solubilized $\alpha 7$-nAChRs were immunoprecipitated with monoclonal antibody (mAb) 319 and radiolabeled with ${ }^{125} \mathrm{I}-\alpha$ Bgt $\left({ }^{125} \mathrm{I}-\alpha-\right.$ bungarotoxin) (Conroy et al., 2003). Total protein was measured using the Bradford assay (Bio-Rad Protein Assay). The $\alpha 7 \mathrm{RNAi}-1$ construct was used for all experiments reported here.

Tissue preparation. Mice were anesthetized by intraperitoneal injection of $10 \mathrm{mg} / \mathrm{ml}$ ketamine and $1 \mathrm{mg} / \mathrm{ml}$ xylazine in sterile $0.9 \% \mathrm{NaCl}$ at a volume of $0.01 \mathrm{ml} / \mathrm{g}$ body weight. Toe pinch was used to determine effectiveness of anesthesia. Animals were transcardially perfused with $4 \%$ paraformaldehyde in PBS. Brains were removed and postfixed in $4 \%$ paraformaldehyde in PBS overnight, and then equilibrated in 30\% sucrose. Next, the tissue was frozen, and coronal slices $(40 \mu \mathrm{m})$ were cut using a cryostat microtome. Sections were dried on Superfrost Plus slides (Thermo Fisher Scientific) and processed immediately for immunostaining.

Immunostaining. Slide-mounted slices were blocked in 5\% normal donkey serum in PBS with 0.5\% Triton X-100 (PBS-TX) for $30 \mathrm{~min}$. Primary antibodies were diluted in the same blocking solution and applied overnight at $4^{\circ} \mathrm{C}$. Primary antibodies included anti-NKCC1 $\mathrm{mAb}$ (1:1000 dilution; Developmental Studies Hybridoma Bank, University of Iowa, Iowa City, IA), anti-5-bromo-2-deoxyuridine (BrdU) $\mathrm{mAb}$
BU1/75 (1:200 dilution; Abcam), and anti-GFP mAb 3E6 (1:1000 dilution; Invitrogen). Slides were then washed three times in PBS-TX for 10 min and incubated with secondary antibodies at 1:500 in PBS-TX for 2-4 $h$ at room temperature. After washing three times in PBS-TX for $10 \mathrm{~min}$, slides were mounted with coverslips using Vectashield mounting medium containing $4^{\prime}, 6^{\prime}$-diamidino-2-phenylindole (DAPI) and stored in the dark at $4^{\circ} \mathrm{C}$ until imaged.

Imaging and quantification. Imaging was performed within $48 \mathrm{~h}$ of immunostaining using a Zeiss Axiovert microscope with 3I deconvolution software for image analysis. For morphological measurements neurons were imaged at $63 \times$ magnification, and a $z$-stack was compiled by acquiring images every $0.5 \mu \mathrm{m}$ through the section. Dendritic measurements were made in ImageJ using the NeuronJ tracing application. Spine counts were taken over a $20 \mu \mathrm{m}$ segment of dendrite located within 100 $\mu \mathrm{m}$ of the granule cell layer boundary. NKCC1 fluorescence measurements were made in a 2 - $\mu \mathrm{m}$-thick ring surrounding the adult-born granule cell nucleus, defined by DAPI and BrdU staining. Cell selection and quantification were performed blind to genotype.

Stereotaxic viral injection. A Moloney's murine leukemia virus construct expressing green fluorescent protein (MMLV-GFP) was provided by Fred Gage (Salk Institute, La Jolla, CA) and modified to express mcherry (MMLV-cherry). Lentiviral constructs were purchased (FG12; Addgene plasmid 14884) and modified to express $\alpha 7$ RNAi and scrambled sequences as described (see above, RNA interference constructs). Viruses were generated by transfecting the constructs into HEK293T cells. Harvest and concentration by ultracentrifugation generated viral titers of $10^{8} \mathrm{PFU} / \mathrm{ml}$ in sterile PBS. The viral suspensions were stereotaxically delivered as described previously (van Praag et al., 2002) at the following position from bregma: anteroposterior, $-2 \mathrm{~mm}$; lateral, 1.7 $\mathrm{mm}$; ventral, $-2 \mathrm{~mm}$. For electrophysiological experiments, a second injection was made from bregma: anteroposterior, $-2.5 \mathrm{~mm}$; lateral, 2 $\mathrm{mm}$; ventral, $-2.2 \mathrm{~mm}$. Animal body temperature was maintained throughout the surgery until anesthesia wore off. After surgery, animals were housed singly and monitored to ensure no signs of infection, pain, or distress.

BrdU labeling. BrdU was injected intraperitoneally at $10 \mathrm{mg} / \mathrm{ml}$ in sterile $0.9 \% \mathrm{NaCl}$ to yield a single dose of $50 \mu \mathrm{g} / \mathrm{g}$ body weight on each of 4 consecutive days. Mice were singly housed for 2 or 4 weeks after the initial injection until tissue preparation. After perfusion, all steps were performed blind to genotype. After cryostat sectioning, slices were dipped in $2 \mathrm{~N} \mathrm{HCl}$ for $30 \mathrm{~min}$ at $37^{\circ} \mathrm{C}$, followed by $0.1 \mathrm{M}$ borate buffer for $10 \mathrm{~min}$ at room temperature. After immunostaining, counts were made of BrdU-positive cells in the first third of the granule cell layer in every fourth section through the entire hippocampus. Adult-born neurons are mostly confined to the first third of the granule cell layer (Zhao et al., 2006).

Electrophysiology. After anesthesia (see above, Tissue preparation), mice were decapitated. Brains were quickly removed from the skull and placed in ice-cold solution containing the following (in mM): 75 sucrose, $87 \mathrm{NaCl}, 2.5 \mathrm{KCl}, 0.5 \mathrm{CaCl}_{2}, 7 \mathrm{MgCl}_{2}, 25 \mathrm{NaHCO}_{3}, 1.25 \mathrm{NaH}_{2} \mathrm{PO}_{4}, 20$ glucose, and bubbled with $95 \% \mathrm{O}_{2} / 5 \% \mathrm{CO}_{2}, \mathrm{pH}$ 7.4. Transverse, 250$\mu \mathrm{m}$-thick hippocampal slices were cut using a vibratome (series 1000 Plus; Technical Products International) and initially stored at $30^{\circ} \mathrm{C}$ in artificial CSF (ACSF) containing the following (in $\mathrm{mm}$ ): $119 \mathrm{NaCl}, 2.5$ $\mathrm{KCl}, 1 \mathrm{NaH}_{2} \mathrm{PO}_{4}, 26 \mathrm{NaHCO}_{3}, 1.3 \mathrm{MgCl}_{2}, 2.5 \mathrm{CaCl}_{2}, 10$ glucose, $\mathrm{pH} 7.4$, and equilibrated with $95 \% \mathrm{O}_{2} / 5 \% \mathrm{CO}_{2}$. Slices were allowed to recover at least $1 \mathrm{~h}$ in oxygenated ACSF at $24^{\circ} \mathrm{C}$ before recording and then continuously perfused with the same solution at a rate of $2-3 \mathrm{ml} / \mathrm{min}$ while recording.

The whole-cell patch-clamp configuration was used both in voltageclamp and current-clamp modes. Microelectrodes (5-8 $\mathrm{M} \Omega$ ) were pulled from borosilicate glass capillaries (Sutter Instrument) with a P-97 pipette puller (Sutter Instrument).

To record spontaneous postsynaptic currents (PSCs), the electrodes were filled with an internal solution containing the following (in $\mathrm{mM}$ ): $135 \mathrm{CsCl}, 4 \mathrm{MgCl}_{2}, 0.1$ EGTA, 10 HEPES, $2 \mathrm{MgATP}$, $0.3 \mathrm{NaGTP}$, and 10 $\mathrm{Na}_{2}$ phosphocreatine, $\mathrm{pH} 7.4$, adjusted with $\mathrm{CsOH}$ to $280-290 \mathrm{mOsm}$. Cells were held at a membrane potential of $-80 \mathrm{mV}$, and currents were recorded for 5 continuous minutes. The resting membrane potential was 
determined in current-clamp mode immediately after establishing the whole-cell configuration. The internal solution consisted of the following (in mM): $125 \mathrm{~K}$-gluconate, $15 \mathrm{KCl}, 8 \mathrm{NaCl}, 2$ EGTA, 10 HEPES, 4 MgATP, $0.3 \mathrm{NaGTP}$, and $10 \mathrm{Na}_{2}$ phosphocreatine, $\mathrm{pH} 7.3$, adjusted with $\mathrm{KOH}$ to $280-290 \mathrm{mOsm}$. Cells with absolute leak current $>100 \mathrm{pA}$ at the holding potential $\left(V_{\text {hold }}\right)$ were discarded.

For perforated-patch recordings, gramicidin was diluted in the pipette solution (in mm: $135 \mathrm{CsCl}, 4 \mathrm{MgCl}_{2}, 0.1$ EGTA, $10 \mathrm{HEPES}$, pH 7.4, 300 mOsm) to a final concentration of $50 \mu \mathrm{g} / \mathrm{ml}$ immediately before use. Pipettes had resistances of 5-8 M . Small voltage steps $(10 \mathrm{mV}, 50 \mathrm{~ms})$ were evoked before extracellular stimulation to monitor membrane and access resistance. If the holding current or either resistance changed significantly, the experiment was discarded. Extracellular stimulation ( $80-$ $240 \mu \mathrm{A}$ and $0.2 \mathrm{~ms}$ duration, $0.1 \mathrm{~Hz}$ ) was performed using a concentric bipolar electrode (125 $\mu \mathrm{m}$ diameter; Frederick Haer Company), with a pulse generator (Master-8; A.M.P.I.) coupled through a stimulus isolator (S.I.U. 90; Neuro Data Instruments). The stimulation electrode was placed on the granule cell layer $300 \mu \mathrm{m}$ away from the recorded cell. During the recording of evoked GABAergic PSCs, the cells were perfused with oxygenated ACSF containing CNQX $(20 \mu \mathrm{M})$ and APV $(20 \mu \mathrm{M})$ to block glutamatergic PSCs and isolate monosynaptic GABAergic PSCs. Recordings were performed under voltage clamp at multiple holding potentials. Peak current amplitude and holding potential were plotted to yield the chloride equilibrium potential $\left(E_{\mathrm{Cl}}\right)$ from a linear fit of the $I-V$ curve for each cell. As a control for perforated-patch integrity, in some cells $E_{\mathrm{Cl}}$ was redetermined after establishing a whole-cell configuration and adjusting the intracellular chloride concentration to yield a slightly positive $E_{\mathrm{Cl}}(2.7 \mathrm{mV})$. The measured values in these cases were in reasonable agreement with predicted values (supplemental Fig. $2 \mathrm{~A}$, available at www.jneurosci.org as supplemental material). To ensure PSCs were GABAergic, gabazine was used to block $\mathrm{GABA}_{\mathrm{A}}$ receptors after $E_{\mathrm{Cl}}$ acquisition and demonstrate loss of the evoked events (supplemental Fig. $2 B$, available at www.jneurosci.org as supplemental material). Current kinetic measurements were made from five or more averaged traces acquired at $-80 \mathrm{mV}$ holding potential. Current rise time was determined between 40 and $100 \%$ of peak amplitude using a single exponential best fit. Current decay was determined between 10 and $90 \%$ of peak amplitude. Since the best fit for decay was either one or two exponentials, weighted decay was calculated using the equation $A_{1} \tau_{1}+A_{2} \tau_{2}$, where $A$ is the relative amplitude and $\tau$ is the decay constant for each component.

All recordings were collected using a MultiClamp 700A amplifier (Molecular Devices), filtered at $2 \mathrm{kHz}$, and digitized at $5 \mathrm{kHz}$ with pCLAMP 9 software (Molecular Devices); analysis was performed with Clampfit 9.2 software.

Statistical analysis. Student's $t$ test ( $t$ test) was used for comparing means if single pairs were involved. One-way ANOVA with Bonferroni's post hoc test was used for comparing means for three or more groups. Kolmogorov-Smirnov (KS) statistical analysis was used to compare cumulative frequency distributions. ${ }^{*} p<0.05,{ }^{* *} p<0.01,{ }^{* * *} p<0.001$.

Materials. All reagents were purchased from Sigma-Aldrich, unless otherwise indicated.

\section{Results}

\section{Reduced survival of adult-born $\alpha 7 \mathrm{KO}$ neurons through the} critical period

To determine whether $\alpha 7$-nAChRs contribute to cholinergic regulation of adult-born neuron survival (Cooper-Kuhn et al., 2004; Kaneko et al., 2006), we birthdated adult-born neurons in wild-type (WT) and $\alpha 7 \mathrm{KO}$ young adult mice by injecting BrdU and following their fate. Hippocampal slices were taken for BrdU immunostaining 2 and 4 weeks later, to allow quantification before and after the critical period for activitydependent survival (Tashiro et al., 2006). No difference was seen in the number of BrdU-labeled cells in the dentate gyrus of WT and $\alpha 7 \mathrm{KO}$ mice at 2 weeks (Fig. 1). A clear difference was found, however, at 4 weeks. At this time, $\alpha 7 \mathrm{KO}$ mice had significantly fewer BrdU-labeled granule neurons than did
A
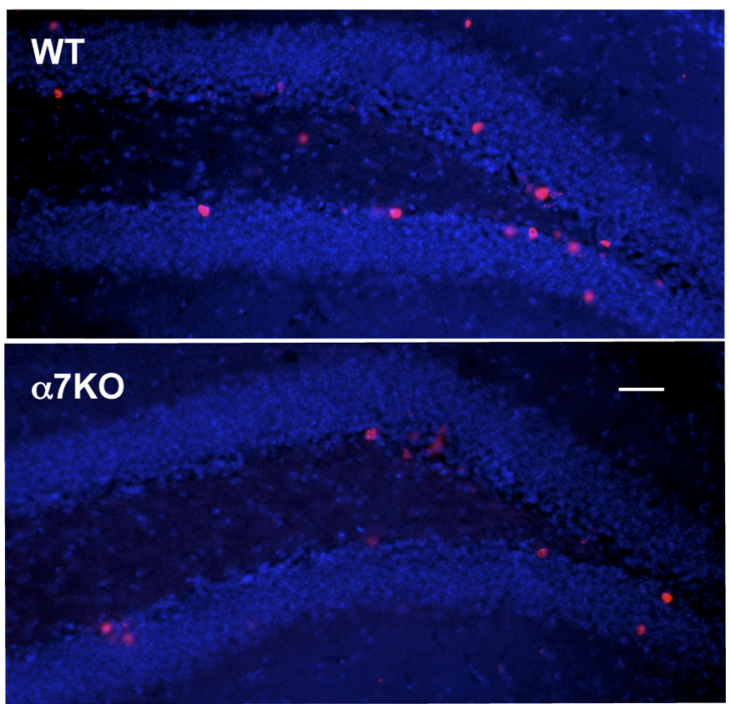

B

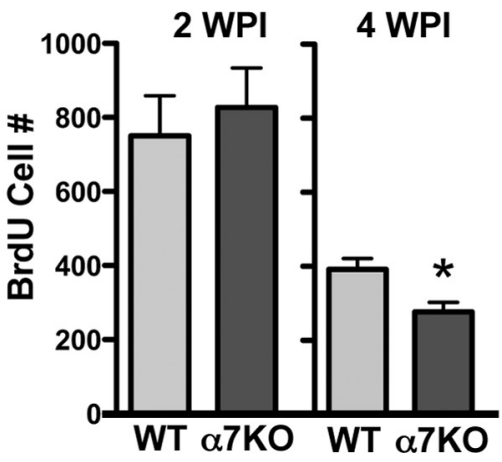

Figure 1. Absence of $\alpha 7-n A C h R s$ decreases the chance of survival for adult-born neurons during the critical period. $\boldsymbol{A}$, Immunofluorescent images of the dentate gyrus showing BrdU (red) and DAPI (blue) staining 4 weeks after injection of BrdU to WT (top) and $\alpha 7$ KO (bottom) mice. $\boldsymbol{B}$, Quantification of BrdU-immunopositive cells at 2 weeks (left; 2 WPI) and 4 weeks (right; 4 WPI) post-BrdU injection (mean \pm SEM; $n=4$ mice per condition). ${ }^{*} p<0.05$, Student's $t$ test. Scale bar, $40 \mu \mathrm{m}$.

WT mice (Fig. 1). The results indicate that $\alpha 7-\mathrm{nAChR}$ signaling is necessary for optimal adult-born neuron survival through the critical period occurring between 2 and 4 weeks after neuronal birth.

Because survival through the critical period depends on glutamatergic signaling (Tashiro et al., 2006), we tested whether adult-born $\alpha 7 \mathrm{KO}$ neurons receive reduced synaptic input. This was done by first labeling adult-born neurons in vivo using stereotaxic injection of MMLV-GFP, which can express only in dividing cells. Labeling is mostly confined to neurons born within a $3 \mathrm{~d}$ window after virus injection (Zhao et al., 2006). Three weeks later, we prepared fresh hippocampal slices, identified GFPexpressing neurons in the dentate gyrus region, and performed patch-clamp recording in voltage-clamp mode (Fig. 2 A). Adultborn $\alpha 7 \mathrm{KO}$ neurons had significantly fewer spontaneous PSCs than did WT neurons, and their PSCs were smaller in size (Fig. $2 B$ ). [Pharmacological blockade of glutamatergic and GABAergic transmission eliminated both spontaneous and evoked PSCs (see below) (Ge et al., 2006).] The results indicate that, in the absence of $\alpha 7$-nAChRs, adult-born neurons receive less synaptic activity, offering a possible explanation for their reduced chances of surviving through the critical period. 
A

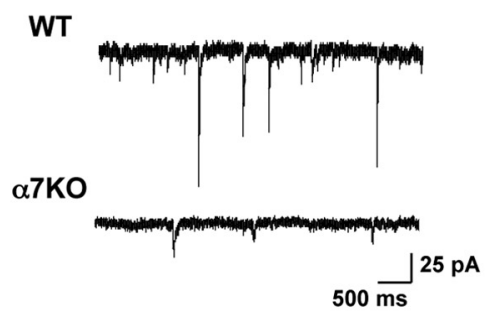

B

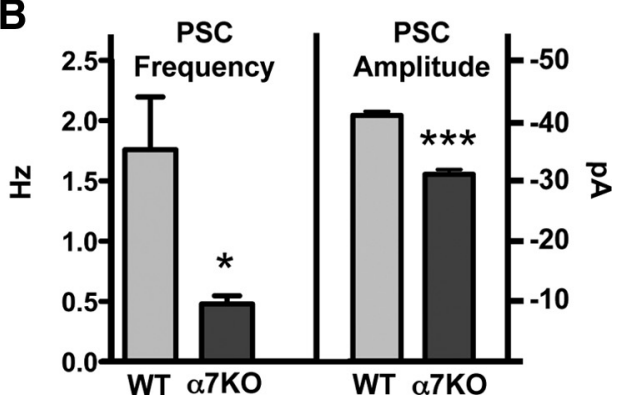

Figure 2. Adult-born neurons lacking $\alpha 7$-nAChRs receive less synaptic activity than normal. $\boldsymbol{A}$, PSCs recorded in 3-week-old adult-born neurons at $-80 \mathrm{mV}$ holding potential, identified by GFP labeling from MMLV-GFP injection in vivo 3 weeks earlier: WT (top), $\alpha 7 \mathrm{KO}$ (bottom). $B$, PSC frequency (left) and amplitude (right) for WT and $\alpha 7 \mathrm{KO}$ neurons (mean \pm SEM; $n=6$ WT and 5 $\alpha 7$ KO neurons). ${ }^{*} p<0.05,{ }^{* * *} p<0.001$, Student's $t$ test.
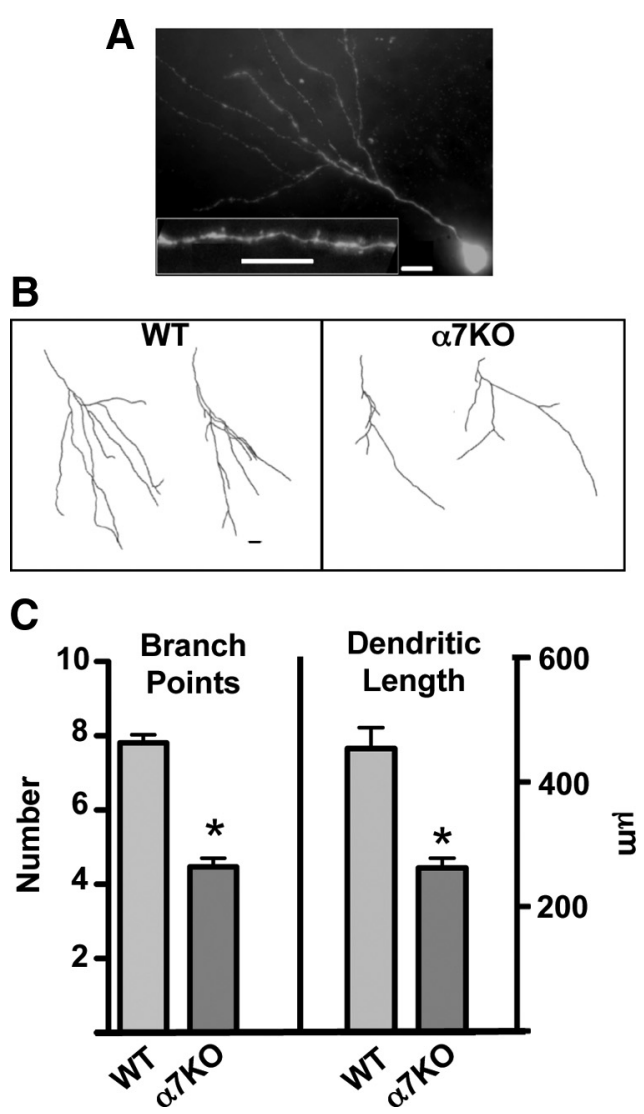

Figure 3. Reduced dendritic arbors are found for 3-week-old adult-born neurons in mice lacking $\alpha 7$-nAChRs when analyzed by MMLV-GFP labeling in vivo. $A$, Deconvolved $z$-stack image of an adult-born granule neuron 3 weeks after the mouse was stereotaxically injected with MMLV-GFP in the dentate gyrus. Digitally magnified dendritic segments (inset) were used for measurement of spine numbers. $\boldsymbol{B}$, Traces of dendrites from granule neurons in WT (left) and $\alpha 7$ KO (right) mice 3 weeks after labeling with MMLV-GFP. C, Quantification of dendritic properties in terms of dendritic branch points (left) and dendritic length (right) of cells as in $\boldsymbol{B}$ (mean $\pm \mathrm{SEM} ; n=3$ mice per condition with $>4$ cells per animal). ${ }^{*} p<0.05$, one-way ANOVA with Bonferroni's post hoc test for multiple comparisons. Scale bars, $10 \mu \mathrm{m}$.

\section{Reduced dendritic arbors on adult-born $\alpha 7 \mathrm{KO}$ neurons}

To determine whether the reduced synaptic input to adult-born $\alpha 7 \mathrm{KO}$ neurons possibly reflected fewer synapses being present on the cells, we performed a morphological analysis. Young adult WT and $\alpha 7 \mathrm{KO}$ mice were injected with MMLV-GFP stereotaxically into the dentate gyrus, and 3 weeks later taken for dendritic measurements of GFP-expressing neurons. Reductions in both

the total dendritic length and in the number of dendritic branch points were found for adult-born $\alpha 7 \mathrm{KO}$ neurons compared with their age-matched WT counterparts (Fig. 3). Because no differences were found in the number of spines per unit length of dendrite $(15 \pm 2$ and $13 \pm 2$ spines $/ 20 \mu \mathrm{m}$ for WT and $\alpha 7 \mathrm{KO}$ dendrites, respectively), we calculate that adult-born $\alpha 7 \mathrm{KO}$ neurons are likely to have substantially fewer spines in aggregate than do WTs and therefore may have proportionately fewer synapses (although this would require other techniques to confirm). A reduction in synapses would account for the reduced number of PSCs and, furthermore, would suggest that $\alpha 7$ nAChR signaling may be necessary for normal dendritic growth on adult-born neurons.

To corroborate an $\alpha 7-\mathrm{nAChR}$ effect on dendritic growth in larger populations of adult-born neurons, we crossed $\alpha 7 \mathrm{KO}$ mice with a GFP-reporter mouse line that expresses GFP under a partial GAD67 promoter. In the mature dentate gyrus of this line, GFP is expressed only in adult-born neurons 1-3 weeks after neurogenesis ( $\mathrm{G}$. Feng, personal communication), before their assuming a glutamatergic fate (Toni et al., 2008). Examining 40 individual neurons from each of three WT/GFP and three $\alpha 7 \mathrm{KO} /$ GFP mice revealed clear differences (Fig. 4A). Comparing either the most complex neurons (Fig. $4 B$ ) or the population histograms of dendritic branch points (Fig. $4 C$ ) showed that adultborn neurons in $\alpha 7 \mathrm{KO}$ mice have a reduced dendritic complexity compared with WTs. KS statistical analysis of the dendritic branch point cumulative frequency histogram confirmed that the morphological differences were highly significant (Fig. 4D). BrdU birthdating of adult-born neurons demonstrated that GFP expression occurred at comparable neuronal ages in the two mouse lines (data not shown). These results confirm that $\alpha 7$ $n A C h R s$ are required for normal dendritic growth in adult-born neurons of the dentate gyrus.

\section{Compromised maturation of adult-born $\alpha 7 \mathrm{KO}$ neurons}

The finding of reduced dendritic arbors on adult-born $\alpha 7 \mathrm{KO}$ neurons raised the question of whether the deficit was specific or might be part of a more global failure of the neurons to mature on schedule. One indicator of maturation is the time during development when the chloride gradient acquires an equilibrium potential $\left(E_{\mathrm{Cl}}\right)$ sufficiently negative as to support inhibitory $\mathrm{GABA}_{\mathrm{A}}$-mediated currents. Before this, GABA is more depolarizing (and often excitatory) because of a reversed chloride gradient caused by early expression of the chloride transporter (importer) NKCC1. Subsequently, NKCC1 expression decreases and the chloride transporter (exporter) KCC2 appears. This inverts the chloride gradient, lowering $E_{\mathrm{Cl}}$ below threshold for action potentials and thereby rendering GABA inhibitory as required for adult function. Importantly, the initial period of depolarizing/excitatory GABAergic signaling is necessary both for early postnatal and adult-born neurons to develop properly and integrate into circuits (Rivera et al., 1999; Ben-Ari, 2002; Payne et al., 2003; Ge et al., 2006).

To determine whether maturation of the chloride gradient is perturbed in adult-born neurons of $\alpha 7 \mathrm{KO}$ mice, we performed gramicidin-induced perforated patch-clamp recording on 3-weekold adult-born neurons. Stereotaxic injection of MMLV-GFP was 
used to label the neurons in vivo 3 weeks before preparing hippocampal slices. Recordings were then obtained from GFP-expressing cells. By measuring the amplitude of the evoked GABAergic PSC as a function of holding potential, we were able to construct $I-V$ plots and calculate the mean reversal potential, this being $E_{\mathrm{Cl}}$. Pharmacological blockers eliminated contributions from glutamatergic PSCs, and the $\mathrm{GABA}_{\mathrm{A}}$ receptor blocker gabazine confirmed that the PSCs being measured under these conditions were GABAergic (supplemental Fig. 2 B, available at www. jneurosci.org as supplemental material). The results reveal that 3 -week-old adultborn $\alpha 7 \mathrm{KO}$ neurons retain an $E_{\mathrm{Cl}}$ that is significantly more positive than that of age-matched WT neurons (Fig. 5A-C). No change was found in the mean resting membrane potential of adult-born $\alpha 7 \mathrm{KO}$ and WT neurons at 3 weeks of age (Fig. $5 C)$. Comparing $E_{\mathrm{Cl}}$ to the resting membrane potential reveals that $\mathrm{GABA}_{\mathrm{A}}$ receptor activation remains depolarizing in adult-born neurons from $\alpha 7 \mathrm{KO}$ mice after it has switched to hyperpolarizing in WT mice.

Maturation of the chloride gradient usually involves loss of NKCC1 and appearance of KCC2 as noted above. To compare NKCC1 levels in $\alpha 7 \mathrm{KO}$ and WT neurons, we birthdated the neurons by BrdU injection in vivo, and then prepared slices 3 weeks later for BrdU and NKCC1 immunostaining. Three-week-old adult-born $\alpha 7 \mathrm{KO}$ neurons in the dentate gyrus displayed substantially higher levels of NKCC1 than did equivalent neurons in WT mice (Fig. $5 D, E)$. NKCC1 immunostaining in mature neurons in the outer third of the granule cell layer, which contains few adult-born neurons, revealed no significant differences between WT and $\alpha 7 \mathrm{KO}$. Loss of $\alpha 7$-nAChR signaling, therefore, delays the reduction in NKCC1 levels in adult-born neurons but does not permanently prevent the reduction from occurring in the broader population of mature granule cells. Together, the results indicate that endogenous signaling through $\alpha 7-\mathrm{nAChRs}$ is required to generate the normal maturation rate of the chloride gradient in adult-born neurons.

Another marker for maturation in adult-born neurons is the appearance of $\mathrm{GABA}_{\mathrm{A}}$ receptors containing $\alpha 1$ subunits. Early appearing forms of the receptor lack the $\alpha 1$ subunit and therefore lack the fast rise and decay kinetics associated with the mature form (Overstreet-Wadiche et al., 2005; Markwardt et al., 2009). We recorded evoked GABAergic PSCs using the perforated patch-clamp configuration on 3-week-old adult-born neurons in fresh slices previously labeled in vivo with MMLV-GFP as described above (Fig. 6A). Measuring the rise and decay kinetics of the events in adult-born neurons revealed significantly longer times in $\alpha 7 \mathrm{KO}$ neurons compared with WTs (Fig. $6 B$ ). This suggests that adult-born $\alpha 7 \mathrm{KO}$ neurons retain expression of immature $\mathrm{GABA}_{\mathrm{A}}$ receptor subunits over a longer developmental period than do WTs. Delayed appearance of $\alpha 1$-containing $\mathrm{GABA}_{\mathrm{A}}$ receptors, a prolonged presence of NKCC1 and depolarizing chloride gradients, and a retarded dendritic arborization in adult-born $\alpha 7 \mathrm{KO}$ neurons indicate that $\alpha 7-\mathrm{nAChR}$ signaling normally helps drive neuronal maturation after neurogenesis in the adult dentate gyrus.
B

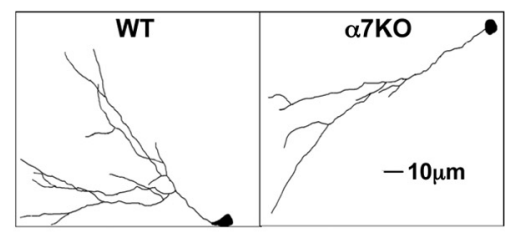

D

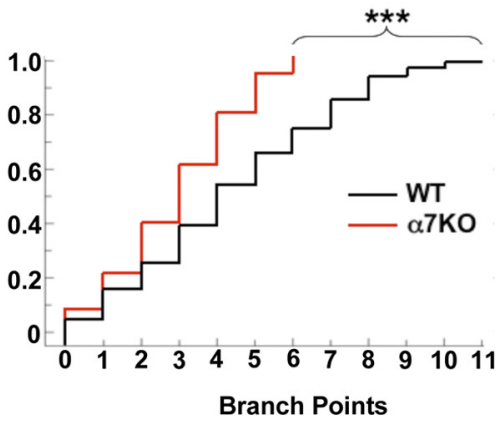

Figure 4. Absence of $\alpha 7-n A C h R s$ causes adult-born neurons to have decreased dendritic complexity as visualized with GAD67 (eporter mice. $A$, GFP expression in adult-born neurons in the dentate gyrus of GAD67-GFP reporter mice viewed at $10 \times$ (left) and Dendritic branch point histograms (mean $\pm S E M ; n=3$ mice per condition; 40 neurons per mouse). $D$, Cumulative frequency plot of dendritic branch points ( $n=120$ granule neurons each for WT and $\alpha 7 \mathrm{KO}$ mice). ${ }^{* * *} p<0.001$, KS test.

\section{Extended vulnerability of the adult-born granule cell population to loss of $\alpha 7-n A C h R s$}

Adult-born $\alpha 7 \mathrm{KO}$ neurons develop behind schedule and have a greater chance of dying during the critical period, but some do survive. The question remains as to whether adult-born $\alpha 7 \mathrm{KO}$ neurons that survive the critical period continue to display deficits after the normal period of development. To examine this, we stereotaxically injected MMLV-GFP in vivo, birthdating adultborn neurons and filling them with fluor for subsequent visualization. After 6 weeks, hippocampal slices were prepared and examined for GFP-expressing cells. The images revealed that adult-born $\alpha 7 \mathrm{KO}$ neurons retain deficits in dendritic length and complexity even after 6 weeks (Fig. 7). This is long after dendritic development has been completed in adult-born WT neurons (Zhao et al., 2006). The results indicate that even those adultborn $\alpha 7 \mathrm{KO}$ neurons that survive the critical period retain morphological defects.

\section{Cell-autonomous action of $\alpha 7$-nAChRs to regulate adult-born maturation}

To gain insight into the mechanism by which $\alpha 7-n A C h R$ signaling regulates adult-born neuron maturation, we tested the hypothesis that the relevant $\alpha 7$-nAChRs act in a cell-autonomous manner (i.e., must be present on the adult-born neurons themselves). To address this, we generated lentiviral constructs encoding $\alpha 7 \mathrm{RNAi}$ with GFP, and then stereotaxically coinjected this virus with MMLV expressing the red fluorescent protein mcherry into WT mice. This dual viral approach allowed us to compare the dendritic growth of $\alpha 7 \mathrm{RNAi}$-expressing (red and green $=$ yellow) and $\alpha 7$ RNAi-lacking (red) adult-born neurons in the same animal (Fig. 8A). Other WT mice were coinjected with lentivirus expressing a scrambled RNAi construct and MMLVmcherry as an additional control. Adult-born neurons expressing $\alpha 7$ RNAi showed significantly reduced dendritic complexity and length compared with either RNAi-lacking adult-born neurons in the same animal or scrambled RNAi-expressing adult-born neuron controls (Fig. $8 B, C$ ). In fact, the values obtained for 
A

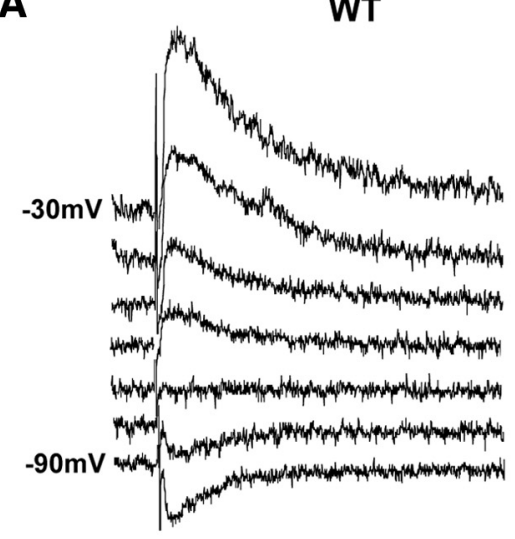

B

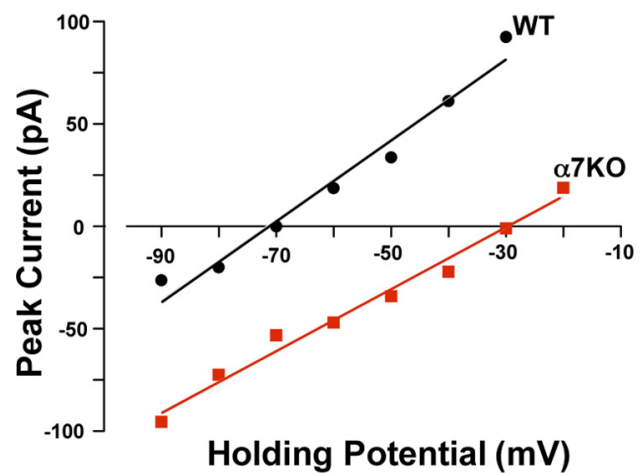

D
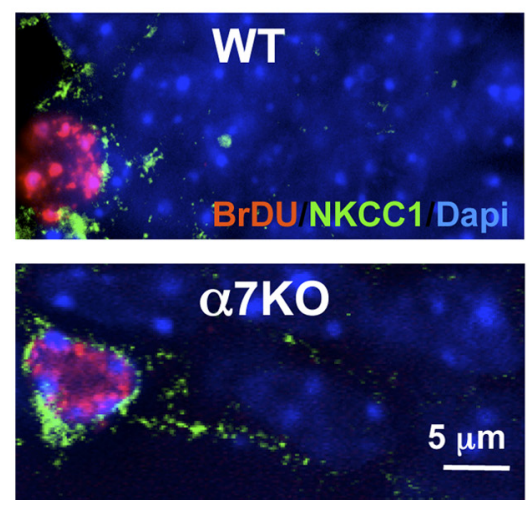

$\alpha 7 K O$

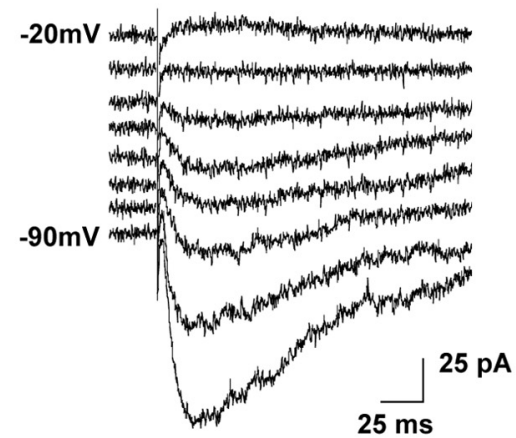

C

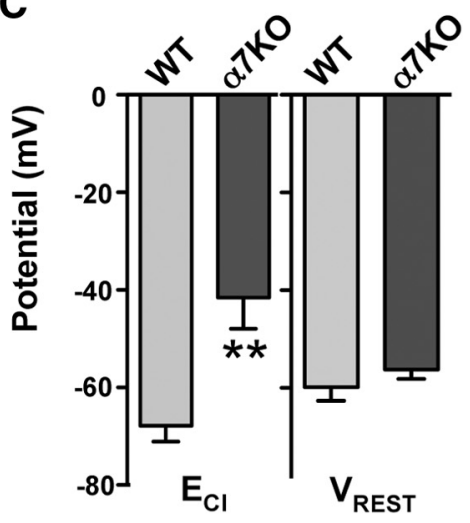

E

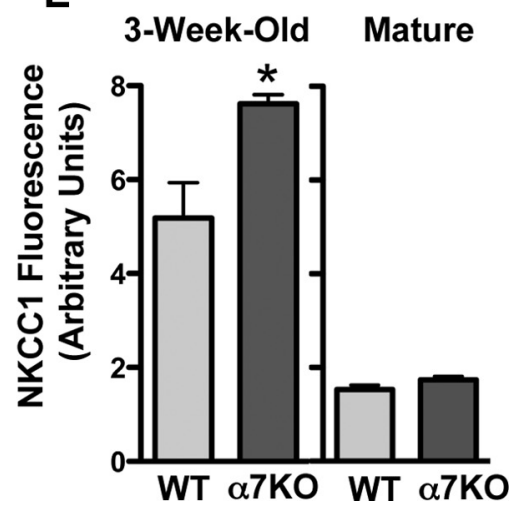

Figure 5. Delayed maturation of the chloride gradient in adult-born $\alpha 7 \mathrm{KO}$ neurons extends the period of depolarizing GABAergic responses. A, Superimposed perforated patch-clamp recordings of GABAergic PSCs evoked in 3-week-old adult-born WT (left) and $\alpha 7 \mathrm{KO}$ (right) neurons at the indicated holding potentials. The neurons were labeled in vivo with MMLV-GFP and visualized in freshly prepared slices at the time of recording. $\boldsymbol{B}$, Peak amplitude of the evoked GABAergic PSC as a function of voltage in a WT (black) and an $\alpha 7 \mathrm{KO}$ (red) neuron as in $\boldsymbol{A}$. C, Interpolated reversal potentials (left; $E_{\mathrm{c} ;} n=6 \mathrm{WT}$ and $5 \alpha 7 \mathrm{~K} 0$ ) and resting membrane potentials (right; $V_{\text {REST; }} n=6$ WT and $8 \alpha 7$ KO) for WT and $\alpha 7$ KO neurons. D, NKCC1 immunostaining (green) of BrdU-labeled (red) 3-week-old adult-born neurons from a WT (top) and $\alpha 7 \mathrm{KO}$ (bottom) dentate gyrus, mounted in DAPIcontaining media to reveal nuclei (blue). $\boldsymbol{E}$, Quantification of NKCC 1 levels in neurons as in $\boldsymbol{D}$ ( 3 weeks of age) or from neurons in the outer third of the granule cell layer (mature) from the same mice (mean \pm SEM; $n=3$ animals per condition; $\geq 10$ neurons per mouse). ${ }^{*} p<0.05,{ }^{* *} p<0.01$, Student's $t$ test.

adult-born neurons expressing $\alpha 7 \mathrm{RNAi}$ were indistinguishable from those obtained for adult-born $\alpha 7 \mathrm{KO}$ neurons of the same age, and both clearly reduced compared with adult-born WT (Fig. 3C).

Lenti- $\alpha 7$ RNAi often infected granule neurons in the outer third of the granule cell layer, which were likely to be fully mature before infection. Quantification of the dendritic arbors of such neurons showed no deficits (supplemental Fig. 3, available at www.jneurosci.org as supplemental material), suggesting that the ability of $\alpha 7 \mathrm{RNAi}$ to affect dendritic morphology is developmentally constrained. To control for potential off-target effects of the $\alpha 7 \mathrm{RNAi}$, we repeated this experiment in $\alpha 7 \mathrm{KO}$ mice. Adult-born neurons in $\alpha 7 \mathrm{KO}$ mice that received $\alpha 7 \mathrm{RNAi}$ were not significantly different from RNAi-lacking adult-born neurons in the same animals (Fig. 8D,E). This indicates that the dendritic arbor defects caused by $\alpha 7$ RNAi are dependent on the presence of $\alpha 7$-nAChRs in those neurons. Together, these results demonstrate that $\alpha 7-\mathrm{nAChR}$ signaling acts in a cellautonomous manner to regulate dendritic arborization of adult-born neurons, a key feature of their maturation.

\section{Discussion}

We show here for the first time that endogenous nicotinic cholinergic signaling through $\alpha 7$-nAChRs in vivo enhances the survival and integration of adult-born neurons in the dentate gyrus. In the absence of functional $\alpha 7$-nAChRs, adult-born neurons have truncated, less complex dendritic arbors, receive fewer PSCs, display GABAergic PSCs with slower kinetics, and maintain an extended period of GABAergic depolarization because of an immature chloride gradient. Together, this indicates that the neurons are in an immature state. Fewer neurons survive the critical period under these conditions, and the survivors have persistent deficiencies in dendritic arborization. As a result, fewer neurons are added to the adult dentate gyrus, thereby over time compromising renewal of the mossy fiber pathway relaying entorhinal input to the hippocampus.

Our results demonstrate that dendritic maturation of adult-born neurons is regulated by cell-autonomous $\alpha 7-n A C h R$ signaling. This excludes the possibility that the $\alpha 7-\mathrm{nAChR}$ effects are indirect (e.g., resulting from $\alpha 7$-nAChR-mediated increases in network activity impinging on the neurons). In other systems, neurotransmitter-mediated regulation of dendritic morphology involves calcium signaling and subsequent changes in gene expression (Borodinsky et al., 2003; Aizawa et al., 2004; Gaudillière et al., 2004; Buttery et al., 2006). Since $\alpha 7$-nAChRs have a high relative permeability to calcium (Bertrand et al., 1993; Seguela et al., 1993), can generate calcium events in hippocampal neurons even in the absence of detectable currents (Fayuk and Yakel, 2007; Szabo et al., 2008), and drive calcium-dependent gene transcription (Hu et al., 2002), this is the most plausible mechanism at present. Transcriptional regulation may also explain $\alpha 7$-nAChR-dependent changes in physiological maturation (Liu et al., 2006). 
The deficits reported here resulted from loss of $\alpha 7$-nAChRs. None involved $\beta 2^{*}$-nAChRs, the other major class of nicotinic receptors in the hippocampus. Both are expressed at early stages by adult-born neurons, and the neurons receive direct cholinergic innervation (Kaneko et al., 2006; Ide et al., 2008). In contrast to $\alpha 7$ nAChRs, however, $\beta 2^{*}$-nAChRs appear to be essential primarily for initial generation of the cells, and only during middle age (Harrist et al., 2004; Mechawar et al., 2004). Differences in activation kinetics, ion permeabilities, surface locations, and tethering to intracellular signaling cascades provide candidate mechanisms enabling $\alpha 7$-nAChRs and $\beta 2^{\star}$-nAChRs to exert distinct regulatory controls (Vernino et al., 1992; Seguela et al., 1993; Alkondon et al., 1997b; Zoli et al., 1998; Fenster et al., 1999; Chang and Berg, 2001; Wooltorton et al., 2003; Alkondon and Albuquerque 2005; Xu et al., 2006). Interestingly, the $\alpha 7$-nAChR dependence is also different from that of NMDA receptors. The latter are required by adult-born neurons for optimal survival but also appear to mediate competitive interactions when functional on other neurons (Tashiro et la., 2006). In contrast, $\alpha 7$-nAChRs are required whether or not other neurons receive input via $\alpha 7-\mathrm{nAChRs}$.

Adult-born neurons examined here underwent their final mitosis in mice that were at least 1 month of age. At this time, the granule cell layer is fully formed, and neurogenesis is confined to the subgranular layer as it is throughout adulthood (Altman and Bayer, 1990; Espósito et al., 2005). Adult-born neurons generated in young and old animals appear to have similar fates with respect to differentiation and morphological end state (Morgenstern et al., 2008; Ahlenius et al., 2009). This suggests that the results obtained here are likely to apply broadly across the population of adult-born neurons in the dentate gyrus, although it should be noted that aged adults may differ from young adults in some respects. Importantly, results from adultborn $\alpha 7 \mathrm{KO}$ neurons here were always compared with agematched adult-born WT neurons.

The $\alpha 7-\mathrm{nAChR}$ requirement for timely maturation of the chloride gradient in adult-born neurons is similar to that reported previously for developing neurons in early postnatal mouse hippocampus and embryonic chick spinal cord (Liu et al., 2006). The mechanisms, however, may differ. Adult neurogenesis proceeds more slowly than in the embryo (Espósito et al., 2005; Overstreet-Wadiche et al., 2006), and adult-born neurons replace preexisting synapses rather than increase the total as seen in the early postnate (Toni et al., 2007). The biggest difference, however, is likely to be the presence of spontaneous waves of excitation seen in much of the developing nervous system, including the dentate gyrus (Ben-Ari et al., 1989; Kasyanov et al., 2004;

A
B

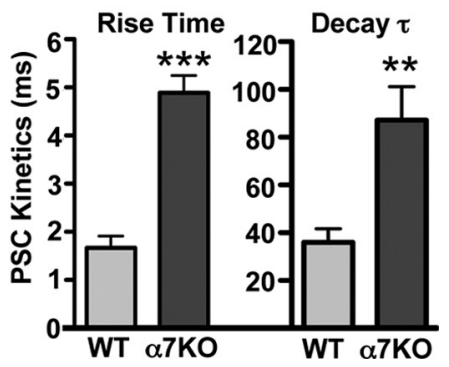

Figure 6. In the absence of $\alpha 7$-nAChRs, GABAergic PSCs display immature kinetics. A, Averaged and normalized evoked GABAergic PSCs from a WT (gray) and an $\alpha 7 K 0$ (black) 3-week-old adult-born neuron. $B$, Quantification of rise time (left) and weighted decay ( $\tau$,

B
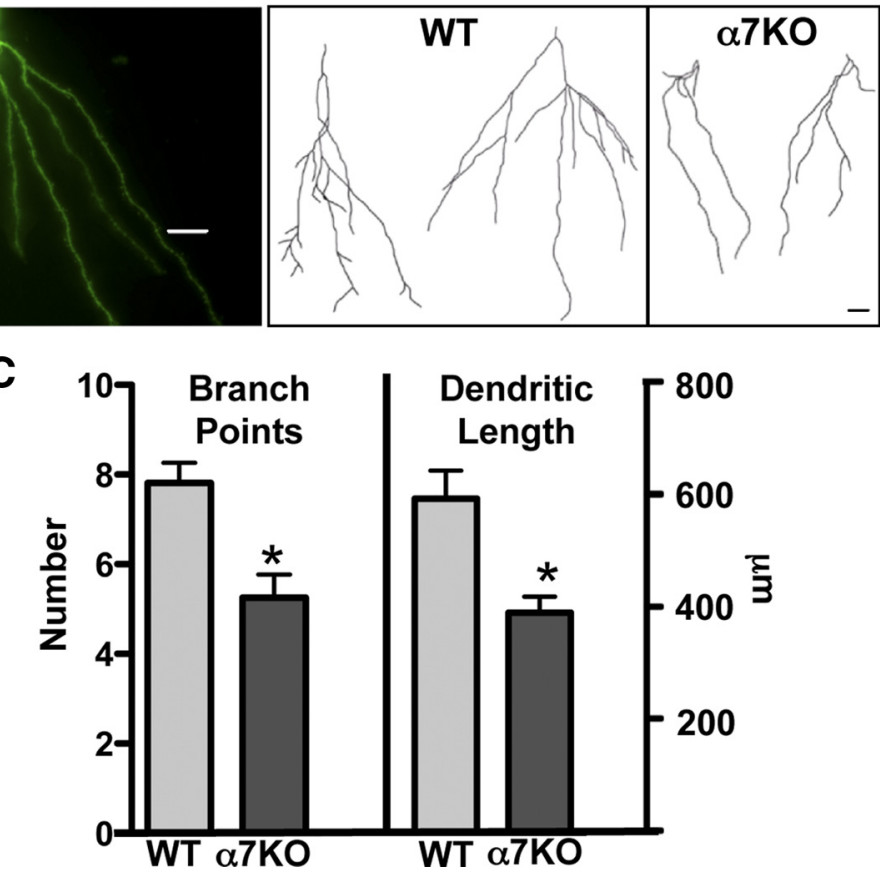

Figure 7. The dendritic deficits found in adult-born $\alpha 7 \mathrm{~K} 0$ neurons persist long after normal dendritic development is complete in WT. $\boldsymbol{A}$, Deconvolved z-stack image of a 6-week-old adult-born neuron from an $\alpha 7 \mathrm{~K} 0$ mouse labeled in vivo by injection of at the time of cell division. $\boldsymbol{B}$, Dendritic arbor traces of 6-week-old adult-born neurons from WT (left) and $\alpha 7$ KO (right) mice. $C$, Dendritic branch points (left) and dendritic length (right) of 6-week-old adult-born neurons visualized by MMLV-GFP labeling (mean $\pm S E M ; n=4$ mice per condition with $>4$ cells per animal). ${ }^{*} p<0.05$, Student's $t$ test. Scale bars, $10 \mu \mathrm{m}$.

Overstreet-Wadiche et al., 2006). In embryonic spinal cord and early postnatal hippocampus, nicotinic activity initiates or enhances these waves (Hanson and Landmesser, 2003; Le Magueresse et al., 2006). The waves may enable nicotinic activity to act ubiquitously (although indirectly) to excite large populations and coordinate their maturation. The adult dentate gyrus has no comparable waves of excitation (Overstreet-Wadiche et al., 2006) and may instead rely on direct cholinergic input to guide the development and integration of adult-born neurons. Nonetheless, $\alpha 7$-nAChRs appear to have some common effects in the early postnatal and adult dentate gyrus on neuronal development: adult-born and early postnatal neurons rely on $\alpha 7$-nAChR signaling to terminate the initial period of GABAergic excitation/depolarization.

A period in which GABA currents are depolarizing (and likely excitatory) is widely thought essential for proper neuronal development and integration for both early postnatal and adult-born neurons (Ben-Ari, 2002; Represa and Ben-Ari, 2005; Tozuka et 
A

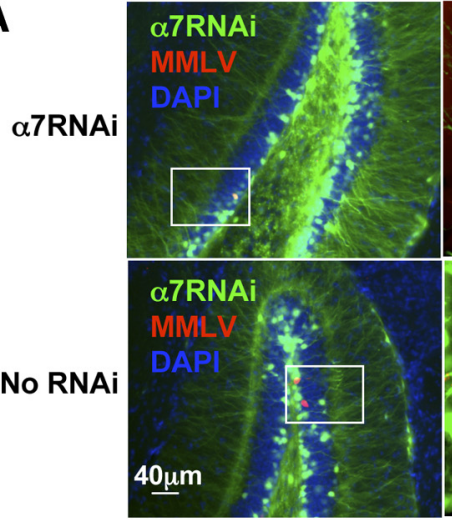

B

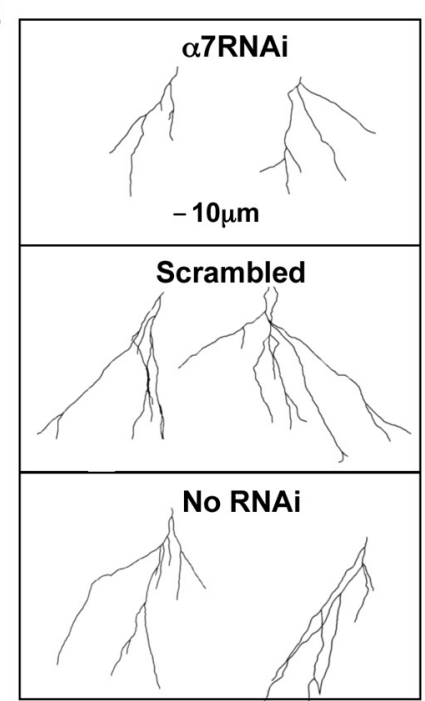

D

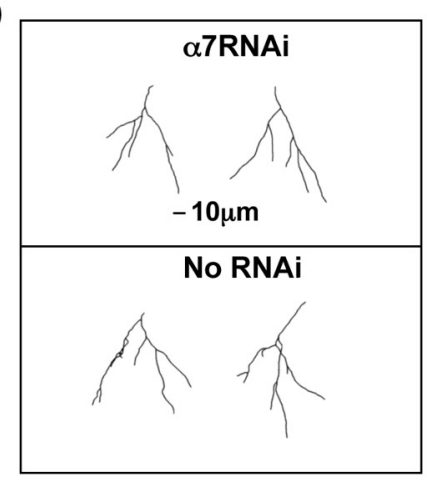

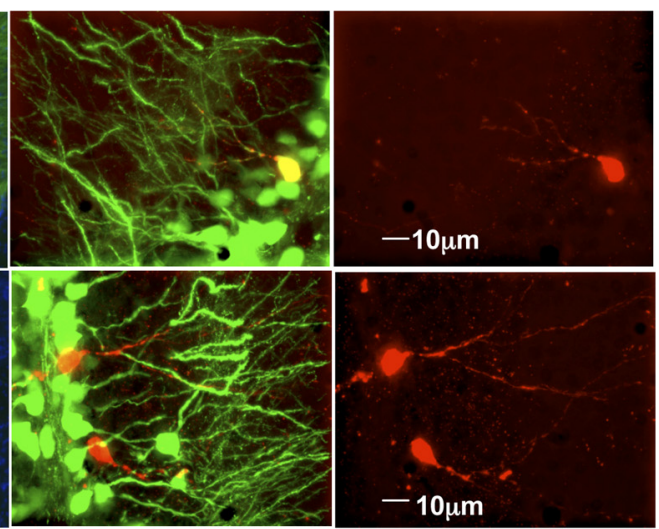

C

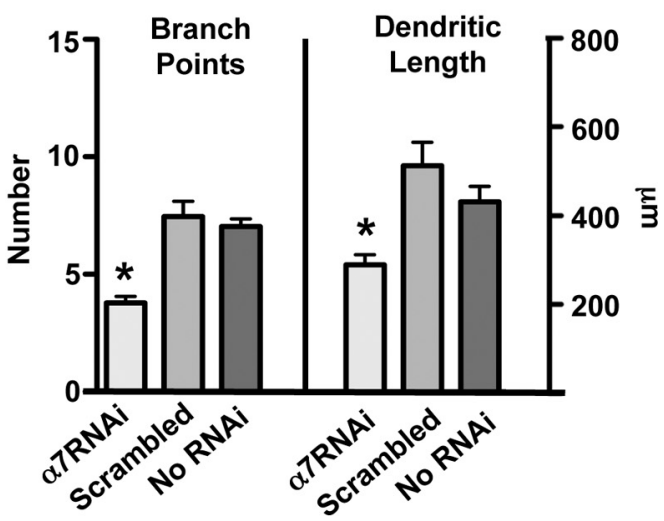

E

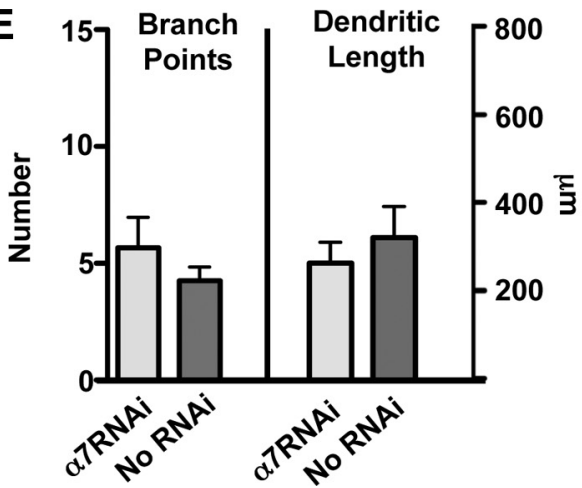

Figure 8. Cell-autonomous signaling through $\alpha 7-n A C h R s$ supports dendritic maturation of adult-born granule neurons $A$, Stereotaxic coinjection of lenti- $\alpha$ 7RNAi (green) and MMLV-mcherry (red) yields both adult-born neurons expressing $\alpha 7$ RNAi (top row; yellow cell) and adult-born neurons lacking RNAi expression (bottom row; red cells) in the same animal. Images are shown at $10 \times$ (left) and magnified at the region of interest (white box) to $63 \times$ (middle and right). $\boldsymbol{B}$, Dendritic arbor traces of 3-week-old adult-born neurons expressing $\alpha$ 7RNAi (top), scrambled RNAi (middle), or lacking RNAi expression in animals injected with lenti- $\alpha$ 7RNAi (bottom). C, Dendritic branch points (left) and dendritic length (right) of 3-week-old adult-born neurons infected as in $\boldsymbol{A}$ and $\boldsymbol{B}$ (mean \pm SEM; $n=3$ mice per condition with $>4$ cells per animal). $\boldsymbol{D}$, Dendritic traces of 3-week-old $\alpha 7 \mathrm{KO}$ adult-born neurons expressing $\alpha 7$ RNAi (top) or lacking RNAi expression in animals injected with lenti- $\alpha 7$ RNAi (bottom). $\boldsymbol{E}$, Dendritic branch points (left) and dendritic length (right) of 3-week-old $\alpha 7 \mathrm{~K} 0$ adult-born neurons (mean \pm SEM; $n=$ 4 mice per condition). ${ }^{*} p<0.05$, one-way ANOVA with Bonferroni's post hoc test for multiple comparisons.

al., 2005; Ge et al., 2006; Cancedda et al., 2007). Extended periods of depolarizing/excitatory GABA signaling, as found in $\alpha 7 \mathrm{KO}$, might therefore be expected to correlate with increased dendritic arborization and innervation. The opposite was found: adultborn $\alpha 7 \mathrm{KO}$ neurons have (1) shorter, less complex dendritic ar- bors; (2) reduced synaptic input; (3) an immature form of $\mathrm{GABA}_{\mathrm{A}}$ receptors apparently lacking $\alpha 1$ subunits (OverstreetWadiche et al., 2005); and (4) increased likelihood of dying during the critical 2-4 weeks after neurogenesis (Tashiro et al., 2006). The results indicate that adult-born neurons require $\alpha 7-\mathrm{nAChR}$ signaling for normal development and integration, advancing them to some trigger point that enables the chloride gradient to mature and render GABA currents inhibitory.

Adult neurogenesis is essential for proper hippocampal function. Adult-born neurons integrate into functional hippocampal networks and are activated by hippocampal-dependent learning tasks (Ramirez-Amaya et al., 2006; Tashiro et al., 2007). Ablation of the precursor cells that normally generate adult-born neurons impairs certain types of hippocampal-dependent learning and memory (Shors et al., 2001, 2002; Rola et al., 2004; Snyder et al., 2005; Winocur et al., 2006). Key functions for adult-born neurons include coding time and place integration (Aimone et al., 2006), spatial pattern separation (Clelland et al., 2009), reinforcement of preexisting memories (Trouche et al., 2009), and transition of memories from hippocampal to cortical circuits (Kitamura et al., 2009). Recently adultborn neurons have been shown to play a role in diminishing addictive behavior and reducing the incidence of relapse (Noonan et al., 2010). Loss of $\alpha 7$-nAChR signaling will cause cumulative deficits to accrue over time in hippocampal circuitry as fewer adult-born neurons survive and those that do are less likely to be appropriately integrated into functioning circuits. The expected outcome would be a pronounced decline in hippocampal function, perhaps most acute for memories that are space and time dependent (Aimone et al., 2006; Clelland et al., 2009; Trouche et al., 2009).

Early deficits in Alzheimer's disease involve loss of cholinergic neurons and a diminution of cholinergic signaling (Whitehouse et al., 1982; Francis et al., 1999; Nordberg, 2001; Lyness et al., 2003; O'Neil et al., 2007). The $\beta$-amyloid peptide, which accumulates during the disease (Selkoe, 1994), impairs choline uptake and acetylcholine release, further compromising cholinergic signaling (Auld et al., 1998; Kar et al., 1998). Moreover, $\beta$-amyloid peptide has been reported to inhibit $\alpha 7-n A C h R$ function either directly or indirectly (Wang et al., 2000a,b; Liu et al., 2001; Pettit et al., 2001; Dougherty et al., 2003; Grassi et al., 2003; Lee and Wang, 2003; Pym et al., 2005), although it has also been reported to have $\alpha 7$ nAChR agonist activity at low concentrations (Dineley et al., 
2001, 2002; Dougherty et al., 2003; Grassi et al., 2003; Wang et al., 2003). Several studies have reported specific decrements in $\alpha 7$ nAChRs associated with Alzheimer's disease (Hellström-Lindahl et al., 1999; Guan et al., 2000; Lee et al., 2000) (but see Rei et al., 2000). The present studies predict that the loss or blockade of $\alpha 7$-nAChRs in Alzheimer's disease would exacerbate the symptoms by decreasing the incorporation of adult-born neurons. Supporting this idea is the observation that donepezil, an acetylcholinesterase inhibitor approved as a drug for treatment of Alzheimer's disease, has been shown to promote adult-born neuron survival during the critical period (Kaneko et al., 2006).

Our results identify $\alpha 7-\mathrm{nAChRs}$ as potential pharmacological targets for amplifying adult-born neuron integration and survival. An impediment to prescribing nicotinic agonists, however, is the observation that prolonged nicotine exposure at concentrations encountered by smokers can have detrimental effects on the survival of adult-born neurons (Abrous et al., 2002; Shingo and Kito, 2005; Scerri et al., 2006). The nicotine-mediated death of adult-born neurons occurs early in their development, whereas the beneficial effects of endogenous $\alpha 7$-nAChR signaling seen here become apparent 2-4 weeks after neurogenesis. Either additional $\mathrm{nAChR}$ subtypes are involved or the manner of receptor activation is critical. This motivates additional examination of mechanisms controlling nicotinic regulation of adult neurogenesis.

\section{References}

Abrous DN, Adriani W, Montaron MF, Aurousseau C, Rougon G, Le Moal M, Piazza PV (2002) Nicotine self-administration impairs hippocampal plasticity. J Neurosci 22:3656-3662.

Ahlenius H, Visan V, Kokaia M, Lindvall O, Kokaia Z (2009) Neural stem and progenitor cells retain their potential for proliferation and differentiation into functional neurons despite lower number in aged brain. J Neurosci 29:4408-4419.

Aimone JB, Wiles J, Gage FH (2006) Potential role for adult neurogenesis in the encoding of time in new memories. Nat Neurosci 9:723-727.

Aizawa H, Hu SC, Bobb K, Balakrishnan K, Ince G, Gurevich I, Cowan M, Ghosh A (2004) Dendritic development regulated by CREST, a calciumregulated transcriptional activator. Science 303:197-202.

Alkondon M, Albuquerque EX (2001) Nicotinic acetylcholine receptors $\alpha 7$ and $\alpha 4 \beta 2$ subtypes differentially control GABAergic input to CA1 neurons in rat hippocampus. J Neurophysiol 86:3043-3055.

Alkondon M, Albuquerque EX (2005) Nicotinic receptor subtypes in rat hippocampal slices are differentially sensitive to desensitization and early in vivo functional up-regulation by nicotine and to block by bupropion. J Pharmacol Exp Ther 313:740-750.

Alkondon M, Pereira EF, Barbosa CT, Albuquerque EX (1997a) Neuronal nicotinic acetylcholine receptor activation modulates $\gamma$-aminobutyric acid release from CA1 neurons of rat hippocampal slices. J Pharmacol Exp Ther 283:1396-1411.

Alkondon M, Pereira EF, Cortes WS, Maelicke A, Albuquerque EX (1997b) Choline is a selective agonist of alpha7 nicotinic acetylcholine receptors in the rat brain neurons. Eur J Neurosci 9:2734-2742.

Altman J, Bayer SA (1990) Migration and distribution of two populations of hippocampal granule cell precursors during the perinatal and postnatal periods. J Comp Neurol 301:365-381.

Auld DS, Kar S, Quirion R (1998) $\beta$-Amyloid peptides as direct cholinergic neuromodulators: a missing link? Trends Neurosci 21:43-49.

Ben-Ari Y (2002) Excitatory actions of GABA during development: the nature of the nurture. Nat Rev Neurosci 3:728-739.

Ben-Ari Y, Cherubini E, Corradetti R, Gaiarsa JL (1989) Giant synaptic potentials in immature rat CA3 hippocampal neurones. J Physiol 416:303-325.

Bertrand D, Galzi JL, Devillers-Thiéry A, Bertrand S, Changeux JP (1993) Mutations at two distinct sites within the channel domain M2 alter calcium permeability of neuronal $\alpha 7$ nicotinic receptor. Proc Natl Acad Sci U S A 90:6971-6975.

Borodinsky LN, O’Leary D, Neale JH, Vicini S, Coso OA, Fiszman ML (2003) GABA-induced neurite outgrowth of cerebellar granule cells is mediated by $\mathrm{GABA}_{\mathrm{A}}$ receptor activation, calcium influx and CaMKII and erk1/2 pathways. J Neurochem 84:1411-1420.

Buttery P, Beg AA, Chih B, Broder A, Mason CA, Scheiffele P (2006) The diacylglycerol-binding protein $\alpha 1$-chimaerin regulates dendritic morphology. Proc Natl Acad Sci U S A 103:1924-1929.

Cancedda L, Fiumelli H, Chen K, Poo MM (2007) Excitatory GABA action is essential for morphological maturation of cortical neurons in vivo. J Neurosci 27:5224-5235.

Chang KT, Berg DK (2001) Voltage-gated channels block nicotinic regulation of CREB phosphorylation and gene expression in neurons. Neuron 32:855-865.

Clelland CD, Choi M, Romberg C, Clemenson GD Jr, Fragniere A, Tyers P, Jessberger S, Saksida LM, Barker RA, Gage FH, Bussey TJ (2009) A functional role for adult hippocampal neurogenesis in spatial pattern separation. Science 325:210-213.

Conroy WG, Liu Z, Nai Q, Coggan JS, Berg DK (2003) PDZ-containing proteins provide a functional postsynaptic scaffold for nicotinic receptors in neurons. Neuron 38:759-771.

Cooper-Kuhn CM, Winkler J, Kuhn HG (2004) Decreased neurogenesis after cholinergic forebrain lesion in the adult rat. J Neurosci Res 77:155-165.

Dineley KT, Westerman M, Bui D, Bell K, Ashe KH, Sweatt JD (2001) $\beta$-Amyloid activates mitogen-activated protein kinase cascade via hippocampal $\alpha 7$ nicotinic acetylcholine receptors: in vitro and in vivo mechanisms related to Alzheimer's disease. J Neurosci 21:4125-4133.

Dineley KT, Bell KA, Bui D, Sweatt JD (2002) $\beta$-Amyloid peptide activates $\alpha 7$ nicotinic acetylcholine receptors expressed in Xenopus oocytes. J Biol Chem 277:25056-25061.

Dougherty JJ, Wu J, Nichols RA (2003) $\beta$-Amyloid regulation of presynaptic nicotinic receptors in rat hippocampus and neocortex. J Neurosci 23:6740-6747.

Espósito MS, Piatti VC, Laplagne DA, Morgenstern NA, Ferrari CC, Pitossi FJ, Schinder AF (2005) Neuronal differentiation in the adult hippocampus recapitulates embryonic development. J Neurosci 25:10074-10086.

Fayuk D, Yakel JL (2007) Dendritic $\mathrm{Ca}^{2+}$ signaling due to activation of $\alpha 7$-containing nicotinic acetylcholine receptors in rat hippocampal neurons. J Physiol 585:597-611.

Fenster CP, Beckman ML, Parker JC, Sheffield EB, Whitworth TL, Quick MW, Lester RA (1999) Regulation of $\alpha 4 \beta 2$ nicotinic receptor desensitization by calcium and protein kinase C. Mol Pharmacol 55:432-443.

Francis PT, Palmer AM, Snape M, Wilcock GK (1999) The cholinergic hypothesis of Alzheimer's disease: a review of progress. J Neurol Neurosurg Psychiatry 66:137-147.

Gaudillière B, Konishi Y, de la Iglesia N, Yao G, Bonni A (2004) A CaMKIINeuroD signaling pathway specifies dendritic morphogenesis. Neuron 41:229-241.

Ge S, Goh EL, Sailor KA, Kitabatake Y, Ming GL, Song H (2006) GABA regulates synaptic integration of newly generated neurons in the adult brain. Nature 439:589-593.

Gough NR (2007) Stimulating neurogenesis to treat Alzheimer's disease. Sci STKE 391:tw 213.

Grassi F, Palma E, Tonini R, Amici M, Ballivet M, Eusebi F (2003) Amyloid $\beta 1-42$ peptide alters the gating of human and mouse $\alpha$-bungarotoxinsensitive nicotinic receptors. J Physiol 547:147-157.

Gray R, Rajan AS, Radcliffe KA, Yakehiro M, Dani JA (1996) Hippocampal synaptic transmission enhanced by low concentrations of nicotine. Nature 383:713-716.

Guan ZZ, Zhang X, Ravid R, Nordberg A (2000) Decreased protein levels of nicotinic receptor subunits in the hippocampus and temporal cortex of patients with Alzheimer's disease. J Neurochem 74:237-243.

Hanson MG, Landmesser LT (2003) Characterization of the circuits that generate spontaneous episodes of activity in the early embryonic mouse spinal cord. J Neurosci 23:587-600.

Harrist A, Beech RD, King SL, Zanardi A, Cleary MA, Caldarone BJ, Eisch A, Zoli M, Picciotto MR (2004) Alteration of hippocampal cell proliferation in mice lacking the beta 2 subunit of the neuronal nicotinic acetylcholine receptor. Synapse 54:200-206.

Hellström-Lindahl E, Mousavi M, Zhang X, Ravid R, Nordberg A (1999) Regional distribution of nicotinic receptor subunit mRNAs in human brain: comparison between Alzheimer and normal brain. Mol Brain Res 66:94-103.

Hu M, Liu QS, Chang KT, Berg DK (2002) Nicotinic regulation of CREB 
activation in hippocampal neurons by glutamatergic and nonglutamatergic pathways. Mol Cell Neurosci 21:616-625.

Ide Y, Fujiyama F, Okamoto-Furuta K, Tamamaki N, Kaneko T, Hisatsune T (2008) Rapid integration of young newborn dentate gyrus granule cells in the adult hippocampal circuitry. Eur J Neurosci 28:2381-2392.

Kaneko N, Okano H, Sawamoto K (2006) Role of the cholinergic system in regulating survival of newborn neurons in the adult mouse dentate gyrus and olfactory bulb. Genes Cells 11:1145-1159.

Kar S, Issa AM, Seto D, Auld DS, Collier B, Quirion R (1998) Amyloid $\beta$-peptide inhibits high-affinity choline uptake and acetylcholine release in rat hippocampal slices. J Neurochem 70:2179-2187.

Kasyanov AM, Safiulina VF, Voronin LL, Cherubini E (2004) GABAmediated giant depolarizing potentials as coincidence detectors for enhancing synaptic efficacy in the developing hippocampus. Proc Natl Acad Sci U S A 101:3967-3972.

Kitamura T, Saitoh Y, Takashima N, Murayama A, Niibori Y, Ageta H, Sekiguchi M, Sugiyama H, Inokuchi K (2009) Adult neurogenesis modulates the hippocampus-dependent period of associative fear memory. Cell 139:814-827.

Kotani S, Yamauchi T, Teramoto T, Ogura H (2008) Donepezil, an acetylcholinesterase inhibitor, enhances adult hippocampal neurogenesis. Chem Biol Interact 175:227-230.

Lee DH, Wang HY (2003) Differential physiologic responses of $\alpha 7$ nicotinic acetylcholine receptors to $\beta$-amyloid1-40 and $\beta$-amyloid1-42. J Neurobiol 55:25-30.

Lee DHS, D'Andrea MR, Plata-Salaman CR, Wang H-Y (2000) Decreased $\alpha 7$ nicotinic acetylcholine receptor protein levels in sporadic Alzheimer's disease hippocampus. Alzheimers Rep 3:217-220.

Le Magueresse C, Safiulina V, Changeux JP, Cherubini E (2006) Nicotinic modulation of network and synaptic transmission in the immature hippocampus investigated with genetically modified mice. J Physiol 576:533-546.

Liu Q, Kawai H, Berg DK (2001) $\beta$-Amyloid peptide blocks the response of $\alpha 7$-containing nicotinic receptors on hippocampal neurons. Proc Natl Acad Sci U S A 98:4734-4739.

Liu X, Wang Q, Haydar TF, Bordey A (2005) Nonsynaptic GABA signaling in postnatal subventricular zone controls proliferation of GFAP-expressing progenitors. Nat Neurosci 8:1179-1187.

Liu Z, Neff RA, Berg DK (2006) Sequential interplay of nicotinic and GABAergic signaling guides neuronal development. Science 314:1610-1613.

Lyness SA, Zarow C, Chui HC (2003) Neuron loss in key cholinergic and aminergic nuclei in Alzheimer's disease: a meta-analysis. Neurobiol Aging 24:1-23.

Maggi L, Sher E, Cherubini E (2001) Regulation of GABA release by nicotinic acetylcholine receptors in the neonatal rat hippocampus. J Physiol 536:89-100.

Maggi L, Le Magueresse C, Changeux JP, Cherubini E (2003) Nicotine activates immature "silent" connections in the developing hippocampus. Proc Natl Acad Sci U S A 100:2059-2064.

Markwardt SJ, Wadiche JI, Overstreet-Wadiche LS (2009) Input-specific GABAergic signaling to newborn neurons in adult dentate gyrus. J Neurosci 29:15063-15072.

Mechawar N, Saghatelyan A, Grailhe R, Scoriels L, Gheusi G, Gabellec MM, Lledo PM, Changeux JP (2004) Nicotinic receptors regulate the survival of newborn neurons in the adult olfactory bulb. Proc Natl Acad Sci U S A 101:9822-9826.

Morgenstern NA, Lombardi G, Schinder AF (2008) Newborn granule cells in the ageing dentate gyrus. J Physiol 586:3751-3757.

Noonan MA, Bulin SE, Fuller DC, Eisch AJ (2010) Reduction of adult hippocampal neurogenesis confers vulnerability in an animal model of cocaine addiction. J Neurosci 30:304-315.

Nordberg A (2001) Nicotinic receptor abnormalities of Alzheimer's disease: therapeutic implications. Biol Psychiatry 49:200-210.

Okano H, Sawamoto K (2008) Neural stem cells: involvement in adultneurogenesis and CNS repair. Philos Trans R Soc Lond B Biol Sci 363:2111-2122.

O’Neil JN, Mouton PR, Tizabi Y, Ottinger MA, Lei DL, Ingram DK, Manaye KF (2007) Catecholaminergic neuronal loss in locus coeruleus of aged female dtg APP/PS1 mice. J Chem Neuroanat 34:102-107.

Overstreet-Wadiche L, Bromberg DA, Bensen AL, Westbrook GL (2005) GABAergic signaling to newborn neurons in dentate gyrus. J Neurophysiol 94:4528-4532.
Overstreet-Wadiche LS, Bensen AL, Westbrook GL (2006) Delayed development of adult-generated granule cells in dentate gyrus. J Neurosci 26:2326-2334.

Payne JA, Rivera C, Voipio J, Kaila K (2003) Cation-chloride cotransporters in neuronal communication, development, and trauma. Trends Neurosci 26:199-206.

Perera TD, Park S, Nemirovskaya Y (2008) Cognitive role of neurogenesis in depression and antidepressant treatment. Neuroscientist 14:326-338.

Pettit DL, Shao Z, Yakel JL (2001) $\beta$-Amyloid1-42 peptide directly modulates nicotinic receptors in the rat hippocampal slice. J Neurosci 21: RC120(1-5).

Pym L, Kemp M, Raymond-Delpech V, Buckingham S, Boyd CA, Sattelle D (2005) Subtype-specific actions of $\beta$-amyloid peptides on recombinant human neuronal nicotinic acetylcholine receptors $(\alpha 7, \alpha 4 \beta 2, \alpha 3 \beta 4)$ expressed in Xenopus laevis oocytes. Br J Pharmacol 146:964-971.

Radcliffe KA, Dani JA (1998) Nicotinic stimulation produces multiple forms of increased glutamatergic synaptic transmission. J Neurosci 18: 7075-7083.

Ramirez-Amaya V, Marrone DF, Gage FH, Worley PF, Barnes CA (2006) Integration of new neurons into functional neural networks. J Neurosci 26:12237-12241.

Rei RT, Sabbagh MN, Corey-Bloom J, Tiraboschi P, Thal LJ (2000) Nicotinic receptor losses in dementia with Lewy bodies: comparisons with Alzheimer's disease. Neurobiol Aging 21:741-746.

Represa A, Ben-Ari Y (2005) Trophic actions of GABA on neuronal development. Trends Neurosci 28:278-283.

Rivera C, Voipio J, Payne JA, Ruusuvuori E, Lahtinen H, Lamsa K, Pirvola U, Saarma M, Kaila K (1999) The $\mathrm{K}^{+} / \mathrm{Cl}^{-}$co-transporter KCC2 renders GABA hyperpolarizing during neuronal maturation. Nature 397:251-255.

Rola R, Raber J, Rizk A, Otsuka S, VandenBerg SR, Morhardt DR, Fike JR (2004) Radiation-induced impairment of hippocampal neurogenesis is associated with cognitive deficits in young mice. Exp Neurol 188:316-330.

Sahay A, Hen R (2007) Adult hippocampal neurogenesis in depression. Nat Neurosci 10:1110-1115.

Scerri C, Stewart CA, Breen KC, Balfour DJ (2006) The effects of chronic nicotine on spatial learning and bromodeoxyuridine incorporation into the dentate gyrus of the rat. Psychopharmacology (Berl) 184:540-546.

Séguéla P, Wadiche J, Dineley-Miller K, Dani JA, Patrick JW (1993) Molecular cloning, functional properties, and distribution of rat brain $\alpha 7$ : a nicotinic cation channel highly permeable to calcium. J Neurosci 13:596-604.

Selkoe DJ (1994) Normal and abnormal biology of the $\beta$-amyloid precursor protein. Annu Rev Neurosci 17:489-517.

Shingo AS, Kito S (2005) Effects of nicotine on neurogenesis and plasticity of hippocampal neurons. J Neural Transm 112:1475-1478.

Shors TJ, Miesegaes G, Beylin A, Zhao M, Rydel T, Gould E (2001) Neurogenesis in the adult rat is involved in the formation of trace memories. Nature 410:372-376.

Shors TJ, Townsend DA, Zhao M, Kozorovitskiy Y, Gould E (2002) Neurogenesis may relate to some but not all types of hippocampal dependent learning. Hippocampus 12:578-584.

Snyder JS, Hong NS, McDonald RJ, Wojtowicz JM (2005) A role for adult neurogenesis in spatial long-term memory. Neuroscience 130:843-852.

Sohur US, Emsley JG, Mitchell BD, Macklis JD (2006) Adult neurogenesis and cellular brain repair with neural progenitors, precursors and stem cells. Philos Trans R Soc Lond B Biol Sci 361:1477-1497.

Szabo SI, Zelles T, Lendvai B (2008) Intracellular $\mathrm{Ca}^{+2}$ dynamics of hippocampal interneurons following nicotinic acetylcholine receptor activation. Neurochem Int 52:135-141.

Tashiro A, Sandler VM, Toni N, Zhao C, Gage FH (2006) NMDA-receptormediated, cell-specific integration of new neurons in adult dentate gyrus. Nature 442:929-933.

Tashiro A, Makino H, Gage FH (2007) Experience-specific functional modification of the dentate gyrus through adult neurogenesis: a critical period during an immature stage. J Neurosci 27:3252-3259.

Toni N, Teng EM, Bushong EA, Aimone JB, Zhao C, Consiglio A, van Praag H, Martone ME, Ellisman MH, Gage FH (2007) Synapse formation on neurons born in the adult hippocampus. Nat Neurosci 10:727-734.

Toni N, Laplagne DA, Zhao C, Lombardi G, Ribak CE, Gage FH, Schinder AF (2008) Neurons born in the adult dentate gyrus form functional synapses with target cells. Nat Neurosci 11:901-907.

Tozuka Y, Fukuda S, Namba T, Seki T, Hisatsune T (2005) GABAergic ex- 
citation promotes neuronal differentiation in adult hippocampal progenitor cells. Neuron 47:803-815.

Trouche S, Bontempi B, Roullet P, Rampon C (2009) Recruitment of adultgenerated neurons into functional hippocampal networks contributes to updating and strengthening of spatial memory. Proc Natl Acad Sci U S A 106:5919-5924.

van Praag H, Schinder AF, Christie BR, Toni N, Palmer TD, Gage FH (2002) Functional neurogenesis in the adult hippocampus. Nature 415:1030-1034.

Vernino S, Amador M, Luetje CW, Patrick J, Dani JA (1992) Calcium modulation and high calcium permeability of neuronal nicotinic acetylcholine receptors. Neuron 8:127-134.

Verret L, Trouche S, Zerwas M, Rampon C (2007) Hippocampal neurogenesis during normal and pathological aging. Psychoneuroendocrinology 32 [Suppl 1]:S26-S30.

Wang HY, Lee DH, D'Andrea MR, Peterson PA, Shank RP, Reitz AB (2000a) $\beta$-Amyloid1-42 binds to $\alpha 7$ nicotinic acetylcholine receptor with high affinity. J Biol Chem 275:5626-5632.

Wang HY, Lee DH, Davis CB, Shank RP (2000b) A $\beta 1-42$ binds selectively and with picomolar affinity to $\alpha 7$ nicotinic acetylcholine receptors. J Neurochem 75:1155-1161.

Wang HY, Li W, Benedetti NJ, Lee DH (2003) $\alpha 7$ Nicotinic acetylcholine receptors mediate $\beta$-amyloid peptide-induced tau protein phosphorylation. J Biol Chem 278:31547-31553.

Whitehouse PJ, Price DL, Struble RG, Clark AW, Coyle JT, Delon MR (1982) Heterogeneity in epidermal basal keratinocytes: morphological and functional correlations. Science 215:1237-1239.

Winocur G, Wojtowicz JM, Sekeres M, Snyder JS, Wang S (2006) Inhibition of neurogenesis interferes with hippocampus-dependent memory function. Hippocampus 16:296-304.

Wooltorton JR, Pidoplichko VI, Broide RS, Dani JA (2003) Differential desensitization and distribution of nicotinic acetylcholine receptor subtypes in midbrain dopamine areas. J Neurosci 23:3176-3185.

Xu J, Zhu Y, Heinemann SF (2006) Identification of sequence motifs that target neuronal nicotinic receptors to dendrites and axons. J Neurosci 26:9780-9793.

Zhao C, Teng EM, Summers RG Jr, Ming GL, Gage FH (2006) Distinct morphological stages of dentate granule neuron maturation in the adult mouse hippocampus. J Neurosci 26:3-11.

Zoli M, Léna C, Picciotto MR, Changeux JP (1998) Identification of four classes of brain nicotinic receptors using $\beta 2$ mutant mice. J Neurosci 18:4461-4472. 